\title{
MENAKAR MASLAHAT OPERASI KELAMIN PERSPEKTIF HUKUM ISLAM
}

\author{
Arisman \\ Fakultas Syari'ah dan Hukum Universitas Islam Negeri Sultan Syarif Kasim \\ Jl. H.R. Soebrantas KM.15 No. 155 Simpang Panam Pekanbaru \\ Email: Arisman@uin-suska.ac.id
}

\begin{abstract}
Humans are unique creatures and never satisfied. Humans dissatisfaction consist of variety things, including their own physical conditions. This matter caused by the reality that humans are born with various advantages and their respective shortcomings. Some people are born with perfect physical conditions, with perfect genital organs as men or women (with one genital organ). But some of people are born with imperfect physique conditions, with multiple genital organs (penis and vagina), or have an imperfect genitals (have one sex but there are organs the sex is not perfect, so the sex is not clear). Though the clarity gender has a certain legal consequenses. In this case they motivated to do genital surgery. The genital surgery that tend to Tashih or Takmil (repair or refinement) is permitted but sex change is prohibited. This is because people born with abnormal genitals can experiencing psychological and social disorders so that they can be excluded and isolated from the lives of normal people and sometimes to find their own way, like prostitute themselves as transvestites or commit homosexuality and lesbianism
\end{abstract}

Key words: Islamic law, genital surgery, maslahat

\section{PENDAHULUAN}

Perkataan operasi atau penggantian kelamin adalah terjemahan dari Bahasa Inggris "transeksual" karena memang operasi tersebut sasaran utamanya mengganti kelamin seorang waria yang menginginkan dirinya menjadi perempuan. Padahal waria digolongkan sebagai laki-laki, karena ia memiliki alat kelamin laki-laki. ${ }^{1}$

Dapat ditarik suatu pengertian bahwa penggantian kelamin (transeksual) ialah pembedahan medis yang bertujuan merubah jenis kelamin laki-laki menjadi perempuan, atau sebaliknya. ${ }^{2}$ Dalam kondisi pertama -merubah laki-laki menjadi wanita-; yang dilakukan adalah mengangkat zakar (penis) beserta kedua buah

\footnotetext{
${ }^{1}$ Mahjuddin, Masa'il Fiqhiyah (Berbagai kasus hukum Islam yang di Hadapi Saat ini), Jakarta: Kalam Mulia, 2003. hlm.17

${ }^{2}$ Muhammad Ibn Muhammad al-Mukhtār al-Jukniy al-Syanqithiy, Ahkam al-Jirāhah alThibbiyyah, ( Jeddah : Maktabah Shohabah, 1415 H), hlm. 199
} 
pelirnya. Setelah itu, tim dokter akan membuat vagina dan membesarkan payudara si pasien. Sedangkan dalam kondisi kedua -merubah perempuan menjadi laki-laki-; yang dilakukan adalah mengangkat payudara, mendisfungsikan saluran reproduksi wanita, dan membikin zakar (penis). Dalam kedua kondisi tadi, pasien diharuskan mengikuti terapi mental dan hormonal tertentu.

Akhir-akhir ini masyarakat dikejutkan dengan adanya kasus pemalsuan jenis kelamin yang berujung proses hukum. Seperti kasus yang menimpa pasangan Alter, dimana ditengarai bahwa "Alter" ini sebenarnya dulu adalah perempuan, yang pada akhirnya berubah menjadi laki-laki. Demikian juga kasus sdr. Agus di Jawa tengah, yang semula laki-laki sekarang telah menjadi perempuan dan sudah melakukan operasi ganti kelamin. ${ }^{3}$ Belum lagi saat ini banyak dijumpai para waria berkeliaran di jalanan untuk mengamen khususnya di dunia perkotaan, bahkan ada di antara mereka yang menodai atribut muslimah dengan memakai kerudung.

Fenomena operasi kelamin sudah lama terjadi bahkan kalau dilihat penjelasan al-Quran, pada masa Nabi Luth dimana kaumnya diazab oleh Allah swt. gara-gara melakukan kema'syiatan yaitu hubungan sejenis. Ironisnya, di media pertelevisian justru ikut menyemarakkan dan mensosialisasikan perilaku kebancian tersebut di berbagai program acara talkshow, parodi maupun humor. Hal itu akan turut andil memberikan legitimasi terhadap figur yang dapat ditiru masyarakat untuk mempermainkan jenis kelamin atau bahkan perubahan orientasi dan kelainan seksual. Bagaimanakah sebenarnya Islam memandang masalah transgender tersebut dan apa apakah ada kemaslahatan dalam operasi kelamin serta merubah jenis kelamin. Inilah yang akan dibahas lebih lanjut.

\section{METODE PENELITIAN}

Tulisan ini menggunakan metode kajian kepustakaan (library research) yang bersifat kualitatif. Pembahasan yang dikemukakan didasari bahan-bahan yang diteliti melalui dalil-dalil al-Qur'an dan Sunnah, kitab-kitab fiqh dan tafsir. Dari kitab-kitab tersebut dikutip berbagai pendapat dan argumentasi para ulama beserta dalil-dalil yang mereka kemukakan, kemudian diambil suatu kesimpulan yang dapat dipahami seperti yang tertera dalam tulisan ini.

\section{MOTIF DAN MACAM-MACAM OPERASI KELAMIN}

\section{Motif Pelaksanaan Operasi Kelamin}

Ada orang yang dilahirkan dengan kondisi fisik yang sempurna, dengan organ kelamin yang sempurna sebagai laki-laki atau perempuan (dengan satu organ kelamin). Namun ada juga orang yang dilahirkan dengan kondisi fisik yang tidak sempurna, dengan organ kelamin ganda (penis dan vagina), atau memiliki kelamin yang tidak sempurna (memiliki satu kelamin namun ada organ kelaminnya tidak sempurna, sehingga jenis kelaminnya tidak jelas). Padahal kejelasan jenis kelamin memiliki akibat hukum tertentu. Dalam hal ini yang bersangkutan termotivasi menjalani operasi kelamin.

\footnotetext{
${ }^{3}$ http://rainbowhairedwarrior.blogspot.co.id/2014/09/kemenangan-cinta-alter-janetransgender.html.
} 
Operasi kelamin juga dilakukan berkaitan erat dengan kebingungan terhadap jenis kelamin yang dimiliki seseorang yang biasa disebut transeksual atau transgender. Transeksual atau transgender dapat diakibatkan oleh faktor bawaan atau faktor lingkungan. Faktor lingkungan berupa pola pendidikan yang keliru yang dialami seseorang di masa kecilnya, misalnya membiarkan anak laki-laki berkembang dalam tingkah laku perempuan, pada masa pubertas dengan homoseksual yang kecewa dan trauma, trauma pergaulan seks dengan pacar, suami atau isteri. Namun perlu dibedakan penyebab transeksual kejiwaan dan bawaan. Pada kasus transeksual karena keseimbangan hormon yang menyimpang (bawaan), menyeimbangkan kondisi normal guna mendekatkan kecenderungan biologis jenis kelamin bisa dilakukan. Mereka yang sebenarnya normal karena tidak memiliki kelainan genetikal maupun hormonal dan memiliki kecenderungan berpenampilan lawan jenis hanya untuk memperturutkan dorongan kejiwaan dan nafsu adalah sesuatu yang tidak menyimpang.

Dengan demikian dalam garis besarnya motif pelaksanaan operasi kelamin ada dua, yaitu motif kejiwaan dan motif bawaan. Dari sisi motif kejiwaan, operasi kelamin dilakukan untuk mengganti alat kelamin yang semula memang normal namun yang bersangkutan tidak merasa cocok dengan alat kelamin yang dimilikinya sebab bertentangan dengan kejiwaannya.

Sedangkan dari sisi motif bawaan, operasi kelamin dilakukan untuk menyempurnakan organ kelamin yang tidak sempurna, atau memperjelas jenis kelamin, bagi yang memiliki kelamin ganda. Sehingga dengan operasi kelamin tersebut, jenis kelamin yang bersangkutan akan menjadi lebih jelas. Dalam cakupan ini operasi kelamin dilakukan juga untuk memperbaiki alat/organ kelamin yang rusak karena sesuatu sebab tertentu, misalnya alat kelamin yang terputus, hangus dan sebagainya. ${ }^{5}$

Dari uraian di atas dapat dikatakan, bahwa motif operasi kelamin yang dilakukan terhadap orang yang memiliki organ kelamin yang tidak sempurna adalah untuk memperbaiki dan menyempurnakan organ kelaminnya. Motif operasi yang dilakukan kepada orang yang memiliki organ kelamin ganda adalah untuk memperjelas identitas jenis kelaminnya. Sedangkan motif operasi kelamin yang dilakukan kepada orang yang memiliki alat kelamin normal dan sempurna adalah untuk pergantian jenis kelamin, baik dari laki-laki menjadi perempuan maupun sebaliknya.

\section{Macam-Macam Operasi Kelamin}

Dalam dunia kedokteran modern dikenal tiga bentuk operasi kelamin, yaitu (1) operasi perbaikan atau penyempurnaan kelamin, yang dilakukan terhadap orang yang sejak lahir memiliki cacat kelamin, seperti zakar (penis), atau vagina yang tidak berlubang; (2) operasi pembuangan salah satu dari kelamin ganda, yang dilakukan terhadap orang sejak lahir memiliki dua jenis kelamin (penis dan vagina); dan (3)

${ }^{4}$ Setiawan Budi Utomo, Fiqih Aktual Jawaban Tuntas Masalah Kontemporer, Cet. I; (Jakarta: Gema Insani Press, 2003), hlm. 171-172.

${ }^{5}$ Ibid., 
operasi penggantian/perubahan jenis kelamin, yang dilakukan terhadap orang yang sejak lahir memiliki kelamin normal. ${ }^{6}$

Pelaksanaan operasi kelamin yang dilakukan terhadap orang yang lahir dengan organ kelamin yang memiliki kelainan, berdasarkan organ kelamin bagian luar dan dalamnya, yaitu operasi kelamin yang dilakukan kepada seseorang yang memiliki satu organ kelamin yang kurang sempurna bentuknya, misalnya ia mempunyai vagina yang tidak berlubang, dan ia memiliki rahim dan ovarium. Operasi dilakukan untuk memberi lubang pada vaginanya. Begitu pula orang yang memiliki penis dan testis tetapi lubang penisnya tidak berada di ujung penis (glans penis) tetapi berada di bawah penisnya, operasi dilakukan untuk dibuatkan lubangnya yang normal.

Operasi kelamin juga dilakukan terhadap seseorang yang memiliki kelamin ganda; penis dan vagina. Operasi dilakukan untuk memperjelas identitas jenis kelaminnya, dengan mematikan organ kelamin yang satu dan menghidupkan organ kelamin yang lain yang sesuai dengan organ kelamin bagian dalam. Misalnya seseorang memiliki dua alat kelamin yang berlawanan; penis dan vagina, serta di samping itu ia juga memiliki rahim dan ovarium yang merupakan ciri khas dan utama untuk jenis kelamin perempuan, operasi dilakukan dengan mengangkat penisnya untuk mempertegas identitas jenis kelamin kewanitaannya. Sebaliknya, operasi bukan untuk mengangkat vaginanya dan membiarkan penisnya, karena berlawanan dengan organ kelamin bagian dalamnya yang lebih vital, yaitu rahim dan ovarium. $^{7}$

Sedangkan operasi perubahan kelamin dilakukan terhadap seseorang yang lahir dalam kondisi normal dan sempurna organ kelaminnya, yaitu penis (zakar) bagi laki-laki dan vagina bagi perempuan yang dilengkapi dengan rahim dan ovarium. (Setiawan Budi Utomo: 2003,171-172).

Jadi, berdasarkan tujuannya, operasi kelamin terbagi dua macam, yaitu operasi untuk perubahan alat kelamin dan penyempurnaan alat kelamin (memperjelas indentitas jenis kelamin). Operasi kelamin untuk penyempurnaan alat kelamin terbagi dua, yakni operasi kelamin untuk menyempurnakan organ kelamin yang mengalami kelainan atau tidak sempurna, dan operasi kelamin untuk membuang salah satu organ kelamin pada orang yang memiliki kelamin ganda (penis dan vagina).

\section{HUKUM OPERASI PERUBAHAN DAN PENYEMPURNAAN KELAMIN}

Permasalahan perubahan dan penyempurnaan kelamin yang muncul di era modern ini belum dikenal dalam abad klasik dan pertengahan, sehingga pembahasan hukumnya tidak dijumpai dalam kitab-kitab fiqh klasik. Menurut Nuruddin Itir (guru besar hadis pada universitas Al-Azhar Cairo) dalam Abdul Aziz Dahlan, dalam kitab fiqh klasik hanyalah berkaitan dengan pembedahan perut mayat yang semasa hidupnya menelan/tertelan uang (koin). ${ }^{9}$ Pembahasan operasi kelamin baru dijumpai

${ }^{6}$ Abdul Azis Dahlan, et al., Ensiklopedi Hukum Islam, Jilid 4 (Cet. V; Jakarta: Ichtiar Baru van Hoeve, 2001), hlm. 1359.

${ }^{7}$ Masjfuk Zuhdi, Masail Fiqhiyah (Cet. X; Jakarta: PT Toko Gunung Agung, 1997), hlm. 173.

${ }^{8}$ Setiawan Budi Utomo, Loc, Cit,.

${ }^{9}$ Abdul Azis Dahlan, et al., op.cit., hlm. 1359. 
dalam hukum Islam kontemporer sejalan dengan perkembangan ilmu pengetahuan dan teknologi.

Terhadap kasus perubahan atau penyempurnaan kelamin tersebut, Majelis Ulama Indonesia (MUI) telah mengeluarkan fatwa, tanggal 12 Rajab $1400 \mathrm{H}$ bertepatan dengan tanggal 1 Juni 1980 M bahwa:

1. Merubah jenis kelamin laki-laki menjadi perempuan atau sebaliknya hukumnya haram, karena bertentangan dengan surat al-Nisa ayat 119 dan bertentangan pula dengan jiwa syara'

2. Orang yang kelaminnya diganti kedudukan hukum jenis kelaminnya sama dengan jenis kelamin semula sebelum dirubah.

3. Seseorang khunsa (banci) yang kelaki-lakiannya lebih jelas boleh disempurnakan kelaki-lakiannya. Demikian pula sebaliknya, dan hukumnya menjadi positif. ${ }^{10}$

Dengan demikian operasi perubahan kelamin yang dilakukan seseorang yang lahir dalam kondisi normal dan sempurna organ kelaminnya, memiliki penis bagi laki-laki atau vagina bagi perempuan yang dilengkapi dengan rahim dan ovarium, tidak dibolehkan dan diharamkan oleh syariat Islam. Operasi perubahan kelamin inilah yang sering dijalani waria.

Ulama kontemporer-termasuk juga MUI- yang mengharamkan waria (lakilaki) dan/atau perempuan yang sempurna kelaminnya menjalani operasi perubahan kelamin tersebut sejalan pula dengan beberapa dalil syar'i, antara lain:

1. Firman Allah dalam QS. al-Hujurat (49): 13

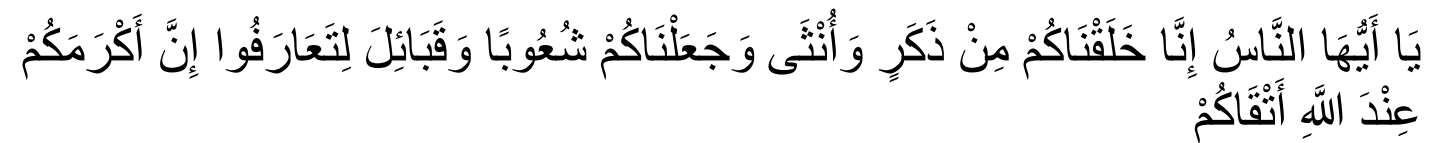

'Wahai Manusia! Sungguh, Kami telah menciptakan kamu dari seorang laki-laki dan seorang perempuan, kemudian Kami jadikan kamu berbangsa-bangsa dan bersuku-suku agar kamu saling mengenal. Sungguh, yang paling mulia di antara kamu di sisi Allah ialah orang yang paling bertakwa. Sungguh, Allah Maha Mengetahui, Maha Teliti. ${ }^{\text {,1 }}$

Ayat ini menegaskan prinsip equality before God and law, manusia memiliki kedudukan yang sama di hadapan Tuhan dan hukum. Yang menentukan tinggi/ rendahnya kedudukan manusia itu bukanlah karena perbedaan jenis kelamin, ras, bahasa, kekayaan, kedudukan dan sebagainya, melainkan karena ketakwaannya kepada Allah. Sebab itu, jenis kelamin yang normal yang dianugerahkan kepada seseorang harus disyukuri dengan cara menerima kodratnya dan menjalankan semua kewajibannya sebagai makhluk kepada Tuhannya sesuai dengan kodratnya pula tanpa mengubah jenis kelaminnya. ${ }^{12}$

10 Departemen Agama R.I, Himpunan Fatwa Majelis Ulama Indonesia, (Jakarta: Ditjen Bimmas Islam dan Penyelenggaraan Haji, 2003), hlm. 335

${ }^{11}$ Departemen Agama R.I, Al-Qur'an dan Terjemahnya (Jakarta: CV Indah Press, 2002), hlm. 745 .

${ }^{12}$ Muhammad bin Muhammad al-Mukhtar al-Syinqithi, Op.Cit, hlm. 201. 


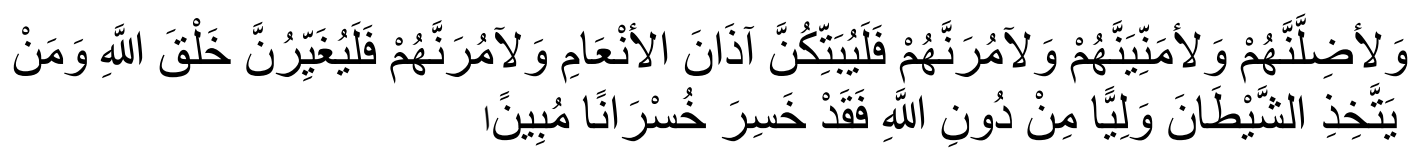

'Dan pasti akan kusesatkan mereka, dan akan kubangkitkan angan-angan kosong pada mereka dan akan kusuruh mereka memotong telinga-telinga binatang ternak, (lalu mereka benar-benar memotongnya), dan akan aku suruh mereka mengubah ciptaan Allah (lalu mereka benar-benar mengubahnya). Barangsiapa menjadikan setan sebagai pelindung selain selain Allah, sungguh dia menderita kerugian yang nyata. 13

M.Quraish Shihab mengemukakan, bahwa ayat ini merupakan lanjutan ucapan setan yang dikandung oleh ayat sebelumnya, dan setan juga berkata: aku benar-benar akan berusaha sekuat kemampuan untuk menyesatkan mereka dari jalan-Mu yang lurus dengan merayu dan mengiming-iming manusia dan akan membangkitkan angan-angan kosong pada mereka sehingga mereka lengah dan atau menunda-nunda kegiatan positif. Aku akan suruh mereka mengubah ciptaan Allah yang melekat dalam diri setiap manusia khususnya fitrah keagamaan dan keyakinan akan keesaan Tuhan lalu benar-benar mereka mengubahnya. Barangsiapa yang mengubah ciptaan Allah itu, ia telah menjadikan setan sebagai pelindung selain Allah, dan jika demikian halnya, sesungguhnya dia menderita kerugian yang nyata. ${ }^{14}$

Termasuk juga dalam pengertian mengubah ciptaan Allah adalah mengebiri, homoseksual, dan lesbian serta praktek-praktek yang tidak sesuai dengan fitrah manusia. Ayat ini dijadikan dasar oleh ulama untuk melarang perubahan bentuk fisik manusia dengan cara-cara apapun termasuk operasi plastic dan operasi perubahan kelamin. $^{15}$

Selaras dengan uraian di atas, menurut Yusuf Qardawi bahwa mengubah jenis kelamin laki-laki yang susunan tubuhnya normal laki-laki menjadi perempuan atau sebaliknya melalui operasi pergantian kelamin adalah haram hukumnya. Karena hal itu merupakan perbuatan setan yang merupakan musuh manusia yang ingin mengeluarkan manusia dari perbuatan istiqamah menjadi perbuatan penyelewengan. Allah telah mengingatkan manusia terhadap ajakan setan dalam QS. al-Nisa ayat 117-119 di atas. ${ }^{16}$ Karena itulah operasi perubahan kelamin laki-laki menjadi perempuan atau sebaliknya haram hukumnya dalam Islam.

Bahkan sebagian ulama mendasarkan keharaman semua jenis operasi tanpa tujuan dengan mengacu kepada ayat 119 surat al-Nisa di atas. Berdasarkan petikan kalimat falayugayyiranna khalqallah, mereka memandang bahwa operasi perubahan kelamin telah melanggar kode etik manusia, mengubah ciptaan Tuhan. Manusia memang diberi otoritas penuh untuk berbuat apa saja di dunia ini. Hanya satu yang tidak boleh dilakukan manusia, yaitu mengubah ciptaan-Nya. Kalau misalnya manusia mengubah ciptaan-Nya, berarti ia memposisikan dirinya sama dengan

${ }^{13}$ Departemen Agama R.I, Al-Qur'an dan Terjemahnya, hlm. 127-128.

${ }^{14}$ M. Quraish Shihab, Tafsir al-Misbah: Pesan, Kesan dan Keserasian Al-Qur'an, Volume 2 (Cet. III; Jakarta: Lentera Hati, 2005), hlm. 591.

${ }^{15}$ Ibid., hlm, 591-592.

${ }^{16}$ Yusuf al-Qardawi, Hady al-Islam Fatawi Mu'asirah, diterjemahkan oleh Abdul Hayyie alKattani, dkk, Fatwa-Fatwa Kontemporer, Jilid 3 (Cet. I; Jakarta: Gema Insani Press, 1995), hlm. 465. 
Tuhan. Itu juga berarti, bahwa ia congkak, sombong karena telah memper-tuhankan diri sendiri. Padahal, yang seperti itu jelas dilarang syara'. ${ }^{17}$

Dengan demikian operasi perubahan kelamin diharamkan dalam hukum Islam karena telah memasuki wilayah otoritas Tuhan serta menimbulkan efek negatif secara biologis dan hukum.

3. Firman Allah dalam QS. al-Rum (30): 30
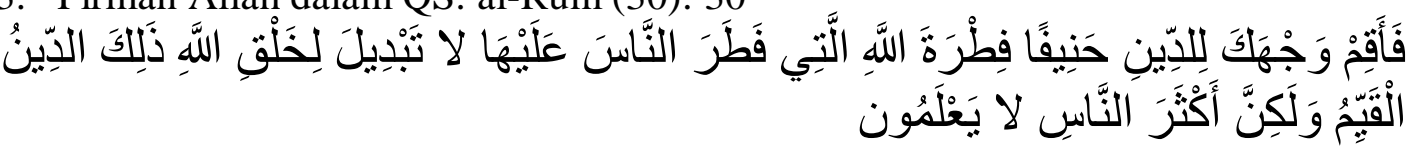

Hadapkanlah wajahmu dengan lurus kepada agama (Islam); (sesuai) fitrah Allah disebabkan Dia telah menciptakan manusia menurut (fitrah) itu. Tidak ada perubahan pada ciptaan Allah. (itulah) agama yang lurus, tetapi kebanyakan manusia tidak mengetahui. ${ }^{18}$

M.Quraish Shihab mengemukakan, bahwa hampir semua ulama tafsir yang terdahulu dan masa kini, memahami ayat 30 surat al-Rum sebagai larangan mengubah atau tidak mungkinnya terjadi perubahan atas fitrah keagamaan manusia. Karena itu memotong kuku, mencukur rambut, khitan bagi laki-laki, melubangi telinga untuk memasang anting-anting dan lain-lain walaupun hal-hal itu juga merupakan perubahan tetapi semua dibenarkan agama karena bukan lahir dari ajaran setan, tidak juga memperburuk apalagi membatalkan fungsinya. ${ }^{19}$

4. Hadis Rasulullah saw yang diriwayatkan oleh Abdullah bin Mas'ud:

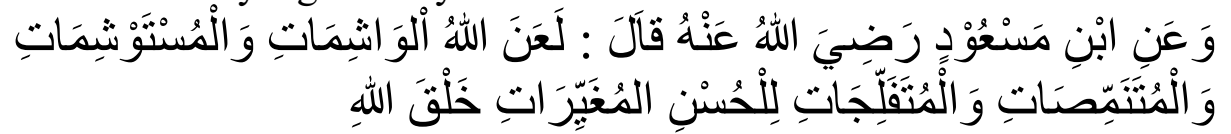

'Allah mengutuk wanita yang membuat tahi lalat palsu dan yang minta dibuatkan, dan mencukur rambut wajahnya, dan yang mengikir giginya (pangur) untuk kecantikan yang mengubah ciptaan Allah.'(HR Bukhari Muslim). ${ }^{20}$

Hadis di atas menunjukkan, bahwa seorang laki-laki atau perempuan yang normal jenis kelaminnya dilarang oleh Islam mengubah jenis kelaminnya, karena termasuk dalam wilayah mengubah ciptaan Allah tanpa alasan yang sah menurut Islam. Begitu pula laki-laki atau perempuan yang lahir normal jenis kelaminnya, tetapi karena lingkungan ia menderita kelainan semacam kecenderungan seksnya yang mendorongnya lahiriah sebagai "banci" atau waria dengan berpakaian dan bertingkah laku berlawanan dengan jenis kelaminnya yang sebenarnya. Hal ini ia juga diharamkan oleh Islam mengubah jenis kelaminnya, sekalipun ia menderita kelainan seksual. Sebab pada hakekatnya organ kelaminnya normal, tetapi psikisnyalah yang tidak normal. Karena itu untuk memulihkan kesehatan mentalnya

${ }^{17}$ Abdul Jalil, dkk., Fiqhi Rakyat Pertautan Fiqih dengan Kekuasaan (Yokyakarta : LKiS, 2002), hlm. 164.

${ }^{18}$ Departemen Agama R.I, Al-Qur'an dan Terjemahnya, hlm. 574.

${ }^{19}$ M. Quraish Shihab, Op.Cit, hlm. 592.

20 Muhammad Fu'ad Abdul Baqi, al-Lu'lu'wa al-Marjan, diterjemahkan oleh Salim Bahreisy, Al-Lu'lu' wal Marjan: Himpunan Hadits Shahih Disepakati oleh Bukhari dan Muslim, no. 1654. Jilid 2 (Cet. II; Surabaya: PT Bina Ilmu, 1982), hlm. 809. 
harus ditempuh melalui pendekatan keagamaan dan kejiwaan, dan bukan melalui operasi perubahan jenis kelamin. ${ }^{21}$

Demikian pula Fatwa MUI yang membolehkan operasi perbaikan atau penyempurnaan kelamin (tashih atau takmil) bagi khunsa, sejalan dengan pendapat ulama klasik dan kontemporer. Alasannya, bahwa jika alat kelamin seseorang tidak berlubang yang menghalangi keluarnya air seni dan mani, baik penis maupun vagina, operasi penyempurnaan atau perbaikan kelamin tersebut dibolehkan, bahkan dianjurkan sehingga kelamin yang normal karena kelainan seperti ini merupakan suatu penyakit yang harus diobati. Jelasnya, orang yang lahir tidak normal jenis kelaminnya, hukum melakukan operasi kelaminnya tergantung kepada organ kelamin luar dan dalam, yang dapat dikelompokkan dalam dua macam, yaitu:

1) Apabila seseorang memiliki organ kelamin ganda, penis dan vagina, untuk memperjelas identitas jenis kelaminnya, ia boleh melakukan operasi kelamin untuk mematikan organ kelamin yang satu dan menghidupkan organ kelamin yang lain sesuai dengan organ kelamin bagian dalam.

2) Apabila seseorang memiliki satu organ kelamin yang kurang sempurna bentuknya, misalnya ia memiliki vagina yang tidak berlubang tetapi ia mempunyai rahim dan ovarium, ia boleh bahkan dianjurkan oleh Islam melakukan operasi kelamin untuk menyempurnakan organ kelaminnya. Begitu pula orang yang memiliki penis dan testis tetapi lubang penisnya berada di bagian bawah penisnya, iapun dibolehkan melakukan operasi kelamin untuk menormalkan penisnya. ${ }^{22}$

Selaras dengan uraian di atas menurut Yusuf Qardawi, bahwa terkadang ditemukan susunan tubuh laki-laki pada diri seorang wanita seperti terdapat alat kejantanan yang tersembunyi (buah zakar/serupanya), dibolehkan wanita itu melakukan operasi kelamin untuk menjadi laki-laki. Bahkan operasi ini menurut hukum Islam malah dianjurkan, karena hal ini pada hakekatnya adalah mengembalikan sesuatu pada asalnya serta meletakkan sesuatu pada tempatnya, dan bukan mengubah ciptaan Allah. Demikian juga orang yang tampak gejala kejantanannya, namun hakekat susunan tubuhnya adalah susunan tubuh wanita. Tetapi organ reproduksi wanita itu seperti sel telur, rahim, vagina dan lain-lainnya tersembunyi, operasi kelamin yang dilakukannya dibolehkan, malah dianjurkan hukum Islam agar ia stabil dan dalam kondisi yang benar tanpa adanya gangguan kesehatan. $^{23}$

Alasan/dalil syar'i yang membolehkan khunsa (banci) menjalani operasi penyempurnaan kelamin, antara lain:

1) Hadis nabi saw yang menganjurkan berobat:

\footnotetext{
${ }^{21}$ Masjfuk Zuhdi, op.cit., hlm. 172.

${ }^{22}$ Muhammad ibn Husein al-Jizani, Fiqh al-Nawazil, dirasah ta'shiliyah tathbiqiyah ( Beirut : Dar Ibnu Jauzi, tt), juz. 4 hlm. 97

${ }^{23}$ Yusuf Qardawi, op.cit., hlm. 465.
} 


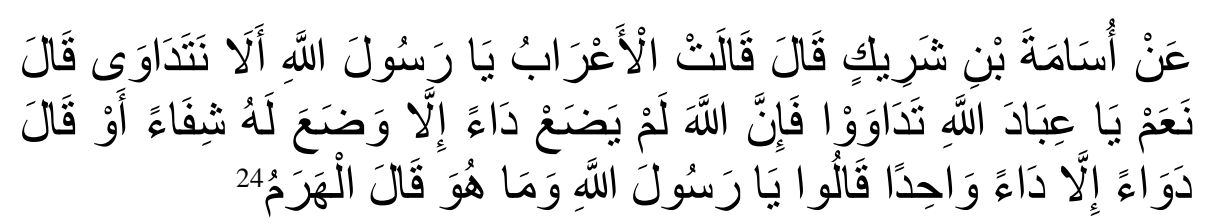

'Usamah bin Syarik berkata: seseorang dari Arab Badui bertanya ya Rasulullah apakah kami perlu berobat? Rasulullah menjawab: Benar. Hai hamba-hamba Allah berobatlah sesungguhnya Allah tidak menurunkan penyakit kecuali telah menurunkan obatnya, kecuali satu penyakit. Para sahabat bertanya: penyakit itu ya Rasulullah? Sabdanya: penyakit ketuaan.'(HR Turmizi)

Alat kelamin yang tidak normal pada hakekatnya merupakan suatu penyakit. Dalam hal ini yang bersangkutan bisa mengalami kelainan psikis dan sosial, sehingga dapat tersisih dan mengasingkan diri dari kehidupan masyarakat normal serta terkadang mencari jalannya sendiri, seperti melacurkan diri menjadi waria atau melakukan homoseksual dan lesbianisme. Padahal tindakan tersebut dilarang oleh Islam. Sebagai suatu bentuk penyakit, operasi penyempurnaan atau perbaikan organ kelamin merupakan salah satu bentuk pengobatan. Karena itulah operasi penyempurnaan atau perbaikan organ kelamin dibolehkan bahkan dianjurkan dalam Islam.

2) Berdasarkan kaedah fiqh: لب المصلحة و دفع المفسدة (mendapatkan kemaslahatan dan menghilangkan kemudaratan). (Masjfuk Zuhdi: 1997, 173). Kaidah yang semakna dengan ini menyebutkan درأ المفاسد اولى من Penerapan dari kaidah ini adalah bahwa, upaya untuk menghindari bahaya yang akan diakibatkan oleh kelainan kelamin lebih baik dari pada mengusahakan suatu kemaslahatan, karena menghindari atau menolak bahaya termasuk suatu kemaslahatan juga.

Orang yang lahir tidak normal jenis/organ kelaminnya terutama yang "banci alami," biasanya mudah mengalami kelainan psikologis dan sosial, akibat masyarakat yang tidak memperlakukannya secara wajar, yang pada gilirannya bisa menjerumuskannya ke dalam dunia pelacuran dan menjadi sasaran kaum homo yang sangat berbahaya bagi dirinya dan masyarakat. Sebab perbuatan anal sex (hubungan seks melalui anus) dan oral sex (hubungan seks melalui mulut) yang biasa dilakukan kaum homo bisa menyebabkan terjangkitnya penyakit AIDS yang sangat ganas yang hingga kini belum ditemukan obatnya itu.

Karena itu jika kemajuan teknologi kedokteran bisa memperbaiki kondisi kesehatan fisik dan psikis atau mental khunsa atau banci tersebut melalui operasi kelamin, Islam membolehkan bahkan menganjurkannya, karena akan memberikan kemaslahatan yang lebih besar dibandingkan dengan bahaya (mafsadat)nya. Ketentuan ini berlaku bagi orang yang

24 Al-Turmizi, al-Jami’ al-Sahih Wahuwa Sunan al-Turmizi, Juz III (Bayrut: Dar al-Fikr, [t.th.]), hlm. 126. Lihat pula CD. Digital al-Hadis al-Syarif, Sunan al-Turmizi, kitab al-Tibb 'an Rasulillah, hadis nomor 1961. 
memiliki organ kelamin ganda atau tidak normal. Karena itu jika seseorang memiliki alat kelamin ganda, penis dan vagina, untuk memperjelas dan memfungsikan secara optimal dan definitif salah satu alat kelaminnya, ia boleh melakukan operasi untuk "mematikan" dan menghilangkan salah satu alat kelaminnya.

Untuk menghilangkan mudarat (bahaya) dan mafsadat (kerusakan) tersebut, menurut Makhluf dan Mahmud Syaltut dalam Setiawan Utomo, syariat Islam membolehkan dan bahkan menganjurkan untuk membuang penis yang berlawanan dengan bagian dalam alat kelaminnya. Sebab itu operasi kelaminnya harus sejalan dengan bagian dalam alat kelaminnya. Karena itu jika seseorang memiliki penis dan vagina, sedangkan pada bagian dalamnya ada rahim dan ovarium, ia tidak boleh menutup lubang vaginanya untuk memfungsikan penisnya. Begitu pula sebaliknya, jika seseorang memiliki penis dan vagina, sedangkan pada bagian dalam kelaminnya sesuai dengan fungsi penis, ia boleh mengoperasi dan menutup lubang vaginanya sehingga penisnya berfungsi sempurna dan identitasnya sebagai laki-laki menjadi jelas. $^{25}$

Dibolehkannya operasi perbaikan atau penyempurnaan kelamin sesuai dengan keadaan anatomi bagian dalam kelamin orang yang memiliki kelainan kelamin atau kelamin ganda, juga merupakan keputusan Nahdlatul Ulama PW Jawa Timur pada seminar "Tinjauan Syariat Islam tentang Operasi Ganti Kelamin," pada tanggal 26-28 Desember 1989 di Pondok Pesantren Nurul Jadid, Probolinggo Jawa Timur. $^{26}$

Dengan demikian, operasi perubahan kelamin haram hukumnya karena kasus ini sebenarnya berakar dari kondisi kesehatan mental yang penanganannya bukan dengan merubah ciptaan Allah melainkan melalui pendekatan spiritual dan kejiwaan (spiritual and psychological therapy). Sedangkan operasi perbaikan atau penyempurnaan kelamin boleh, bahkan dianjurkan atas dasar kemaslahatan bagi yang menjalani operasi kelamin maupun masyarakat yang berinteraksi dengannya.

\section{MASLAHAT DALAM HUKUM ISLAM}

Mashlahah berasal dari kata jadian shâd-lâm-ha, kemudian terbentuk kata shalaha, shaluha, shalâhan, sulûhan dan salâhiyyatan. Secara etimologis berarti manfaat, kebaikan dan kepentingan. ${ }^{27}$ Dalam bahasa Indonesia sering ditulis dan disebut dengan kata maslahat (lawan kata dari mafsadat) yang berarti sesuatu yang mendatangkan kebaikan (keselamatan, dsb), faedah; guna. Sedangkan kemaslahatan berarti kegunaan, kebaikan; manfaat; kepentingan. ${ }^{28}$ Mashlahah merupakan bentuk kata keterangan (masdar) dari kata kerja ( $\left.f i^{\prime} i l\right)$ shalaha, karena itu secara morfologis (sharaf) memiliki pola (wazan) seperti kata manfa'ah. Menurut Ibn al-Manzûr, mashlahah juga merupakan kata benda (isim), bentuk tunggal (mufrad) dari kata

\footnotetext{
${ }^{25}$ Setiawan Budi Utomo, op.cit., hlm. 174.

${ }^{26}$ Ibid., hlm. 175.

27 Atabik Ali dan A. Zuhdi Muhdlor, Kamus Kontemporer Arab-Indonesia, (Cet. VIII; Yogyakarta: Multi Karya Grafika: Pondok Pesantren Krapyak, tt.), hlm. 1741.

${ }^{28}$ Departemen Pendidikan dan Kebudayaan, Kamus Besar Bahasa Indonesia (Cet. VII; Jakarta: Balai Pustaka, 1996), hlm. 634.
} 
mashâlih yang jamak. ${ }^{29}$ Bentuk kata kerja shaluha, menurut al-Fayumi mempunyai pengertian yang berlawanan dengan fasada, yang berarti rusak atau binasa. Al-Razi dan al-Fairuzabad juga memberikan pendapat yang sama. ${ }^{30}$ Arti kata mashlahah dalam kamus al-Munjîd dilengkapi dengan pengertian kata istashlaha sebagai antonim dari kata istafsada. ${ }^{31}$

Dari penjelasan di atas dapat disimpulkan bahwa segi etimologi kata alMashlahah menunjuk kepada pengertian manfaat dan guna itu sendiri (secara langsung) dan kepada sesuatu yang menjadi sebab (secara tidak langsung) dan melahirkan keduanya (maslahah langsung dan tidak), demikian juga kata alMafsadah.

Sebelum kata mashlahah menjadi suatu istilah yang digunakan dalam membicarakan hukum Islam, orang tidak memerlukan penafsiran atau pengertian khusus, karena pada ghalibnya orang Arab sudah mengerti kata mashlahat ini dipakai dalam rangkaian kalimat. Sementara itu para sahabat Nabi saw yang mempergunakan kata mashlahat ini tidak mempersoalkan definisinya. ${ }^{32}$

Menurut pernyataan fuqaha dan ushuliyyun, bahwa adanya hukum Islam adalah bertujuan untuk memelihara kemashlahahan manusia, sekaligus untuk menghindari kerusakan (mafsadah). Dalam literatur teori hukum Islam, kemashlahahan diistilahkan sebagai maqâshid al-syarî’ah. Penyebutan ini berimplikasi pencarian hikmah dan 'illah, ketika ditetapkannya suatu hukum tertentu. Konsep maqâshid al-syarî'ah juga beragam. Ada teori yang digagas oleh al-Syatibi, ada dari Abu Zahroh dan lain-lainnya, akan tetapi semua teori itu terkait dengan teori maslahah bahkan prinsip teori-teori itu adalah kemashlahahan umat manusia. ${ }^{33}$ Kemashlahahan dianggap sangat penting kaitannya dengan upaya dinamika dan pengembangan hukum karena sebagai sesuatu yang terhubung dengan nilai-nilai filosofis dari hukum-hukum yang disyariatkan Allah kepada manusia. Dengan demikian, istilah mashlahah identik dengan istilah filsafat hukum Islam. Memperdalam kajian filosofis ini, Ibnu Sina berpendapat bahwa, "Hikmah ialah mencari kesempurnaan diri manusia dengan menggambarkan segala urusan dan membenarkan segala hakikat baik yang bersifat teori maupun praktik menurut relatifitas kadar kemampuan manusia." ${ }^{34}$ Muslehuddin menjelaskan hikmah sangat berhubungan dengan 'illah ketika menjadi sistem dialektis antara nalar dan wahyu. ${ }^{35}$

${ }^{29}$ Ibn al-Manzûr, Lisân al- 'Arab. (Juz II). (Beirut: Dar al-Fikr, 1972), hlm. 348

30 Ahmad ibn Muhammad ibn Ali al-Muqri al-Fayumi, Al-Mishbah al-Munîr. (Mesir: Mustafâ al-Bâbî al-Halabî.tt), hlm. 157 Lihat juga al-Fairuzabadi, al-Qamûs al-Muhîth. (Juz I). (Beirut: ttp, 1965), hlm. 277

${ }^{31}$ Luis Maluf, al-Munjîd fi al-Lughat wa al-A 'lâm (Beirut: Dar al-Masyriq, 1987), hlm. 286

${ }^{32}$ Mustafa Zaid, Maslahat fi al-Tasyri' al-Islamiy, Dar al-Fikr al-'Arabiy, Mesir, 1964, hlm. 19 Juz 2. hlm.4

${ }^{33}$ Al Syatibi, Al-Muwafaqot Fi Ushul al-Syari'ah, Beirut : Dar al-Kutub al-Ilmiyah, 2011),

34 Fathurrahman Djamil, Filsafat Hukum Islam. (Jakarta: Logos Wacana Ilmu, 1997), hlm. 68

${ }^{35}$ Muhammad Muslehuddin, Philosophy of Islamic Law and Orientalists. (Lahore: Islamic Publication Ltd, 1980), hlm. 165 


\section{SISI MASLAHAT DALAM PERUBAHAN KELAMIN}

Dalam realitas dalam kehidupan manusia, orang yang dilahirkan sebagai "banci alami," atau khunsa yang tentunya mengalami ketidakpastian dari sisi hukum karena hukum hanya mengenal dua jenis kelamin, yakni laki-laki dan perempuan. Sehingga dengan adanya operasi kelamin itu identitas jenis kelaminnya menjadi jelas yang pada gilirannya akan memudahkan yang bersangkutan dalam melakukan perbuatan hukum. Karena itulah Majelis Ulama Indonesia memutuskan bahwa manusia yang mengalami gangguan identitas jenis kelamin (khunsa) dalam pandangan Islam adalah manusia yang wajar dan tidak tercela. Karena itu masyarakat diharapkan agar bisa menerima dan memperlakukan waria yang telah menjalani operasi perbaikan atau penyempurnaan kelamin secara manusiawi, tidak mengucilkan dan tidak memberikan perlakuan yang justru bisa menambah penderitaan bagi mereka. ${ }^{36}$

Fatwa MUI yang membolehkan banci (khunsa) melakukan operasi penyempurnaan atau perbaikan kelamin dalam implementasinya menimbulkan beberapa akibat hukum. Demikian juga fatwa MUI yang melarang (mengharamkan) waria melakukan operasi perubahan kelamin.

a. Banci (Khunsa) yang menjalani Operasi Penyempurnaan/Perbaikan Kelamin

Banci (khunsa) yang menjalani operasi penyempurnaan atau perbaikan kelamin berakibat pada berubahnya jenis kelamin serta kedudukannya sebagai subyek hukum. Karena itu setelah seorang banci menjalani operasi perbaikan/ penyempurnaan jenis atau organ kelaminnya, seharusnya ia segera mengajukan permohonan kepada lembaga peradilan untuk melegitimasi status jenis kelaminnya yang "baru" untuk menghindari konflik yang mungkin terjadi dalam perkawinan dan kewarisan.

Sebagai konsekuensi dibolehkannya seorang waria atau banci alami menjalani operasi perbaikan atau penyempurnaan jenis kelaminnya, ia boleh melakukan perkawinan dengan pasangan yang berbeda jenis kelamin dengannya, dan ia berhak mendapat bagian warisan sesuai dengan jenis kelamin "baru"nya. Perubahan status hukum dari waria menjadi laki-laki atau perempuan setelah operasi perbaikan atau penyempurnaan kelamin dapat dibenarkan oleh Islam karena pada hakekatnya Allah hanya menjadikan manusia terdiri dari dua jenis kelamin: laki-laki dan perempuan sebagaimana tersebut dalam QS. al-Nisa (4): 1 dan al-Hujurat ayat 13.

Banci yang telah menjalani operasi penyempurnaan kelamin juga dapat melakukan perkawinan dengan orang yang berlainan jenis kelamin dengannya. Hal ini berlaku baik bagi banci (khunsa) yang memiliki kelamin ganda, maupun banci yang memiliki organ kelamin yang tidak cacat atau tidak sempurna. Demikian banci tersebut dapat memberikan wali dalam perkawinan jika setelah menjalani operasi penyempurnaan kelamin, banci tadi memiliki jenis kelamin laki-laki sesuai dengan organ kelamin bagian luar dan bagian dalamnya sebagai laki-laki.

\footnotetext{
${ }^{36}$ Masjfuk Zuhdi, op.cit., hlm. 178.

${ }^{37}$ Ibid., hlm. 175-176.
} 
b. Waria yang Menjalani Operasi Perubahan Kelamin

Kemajuan ilmu pengetahuan dan teknologi pada era modern sebenarnya dimaksudkan untuk memberikan berbagai kemudahan dalam kehidupan manusia modern. Demikian pula dalam ilmu dan teknologi kedokteran. Bahkan menurut Ibn Khaldun sebagaimana yang dikutip oleh Nurcholish Madjid, kemajuan ilmu kedokteran merupakan ciri suatu peradaban yang maju. ${ }^{38}$

Perkembangan zaman yang kini mencapai tahap pencerahan di bidang sains dan teknologi telah ikut mendorong terjadinya pergeseran dan diverfikasi kebutuhan hidup manusia yang terkadang cenderung ekstrim. ${ }^{39}$

Karena salah satu ciri masyarakat modern yang paling menonjol adalah sikap yang sangat agresif terhadap kemajuan. Didorong oleh berbagai prestasi yang dicapai oleh ilmu pengetahuan dan teknologi, masyarakat modern berusaha mengabaikan etika, bahkan mengesamping-kan peran serta Tuhan dalam aktivitasnya.

Salah satu bentuk produk teknologi yang disalahgunakan pada era modern ini adalah operasi perubahan kelamin. Dalam kasus ini Majelis Ulama Indonesia (MUI) telah mengeluarkan fatwa keharaman operasi perubahan kelamin bagi waria.

Keharaman waria menjalani operasi perubahan kelamin pada hakekatnya selaras dengan problem kedudukan hukum waria tersebut dalam implementasinya. Salah satu problem yang ditimbulkannya berkaitan dengan perkawinan. Dalam hal ini operasi perubahan kelamin dapat menjadi sumber konflik dalam rumah tangga, sebab suami atau isteri yang telah menjalani operasi perubahan kelamin itu pada hakekatnya tidak dapat menjalankan kewajibannya sebagai suami atau isteri yang normal. $^{40}$

Konflik rumah tangga tersebut erat kaitannya dengan hambatan mendapatkan keturunan, padahal hampir semua pasangan suami isteri sangat mendambakan kehadiran anak dalam keluarganya. Sehingga kebahagiaan dalam rumah tangga mengalami gangguan. Dengan demikian operasi perubahan kelamin bertentangan dengan tujuan perkawinan itu sendiri, sebab tujuan perkawinan adalah membentuk rumah tangga yang bahagia sesuai isyarat QS. al-Rum (30): 21

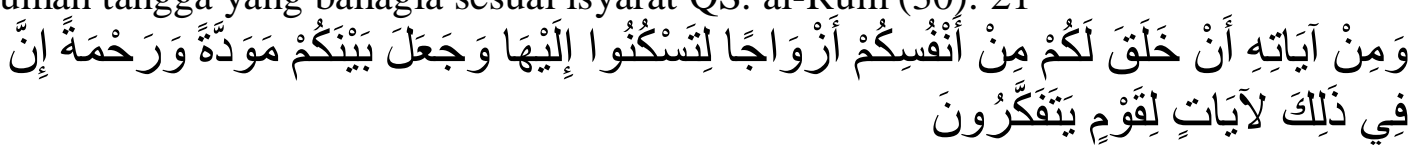

'Dan di antara tanda-tanda (kebesaran)-Nya ialah Dia menciptakan pasanganpasangan untukmu dari jenismu sendiri, agar kamu cenderung dan merasa tenteram kepadanya, dan Dia menjadikan di antaramu rasa kasih dan sayang. Sungguh pada yang demikian itu benar-benar terdapat tanda-tanda (kebesaran Allah) bagi kaum yang berpikir. ${ }^{41}$

Ayat ini berisi petunjuk, bahwa salah satu tujuan perkawinan, adalah terwujudnya kehidupan rumah tangga yang harmonis dan sakinah. Dalam konteks

${ }^{38}$ Nurcholish Madjid, Masyarakat religius (Cet. I; Jakarta: Paramadina, 1997), hlm. 170.

39 Muhammad Azhar Hamim Ilyas (ed.), Pengembangan Pemikiran Keislaman Muhammadiyah: Purifikasi dan Dinamisasi (Cet. I; Yogyakarta: M ajelis Tarjih dan Pengembangan Pemikiran Islam PP Muhammadiyah dan LIPPI, 2000), hlm. 180.

${ }^{40}$ Masjfuk Zuhdi, op.cit., hlm. 174.

${ }^{41}$ Departemen Agama R.I, op.cit., hlm. 572. 
ini, M. Quraish Shihab mengatakan, bahwa kata sakan terambil dari kata sakana yang berarti diam, tenang setelah sebelumnya goncang dan sibuk. Dari makna inilah rumah dinamakan sakan karena dia menjadi tempat memperoleh ketenangan setelah sebelumnya penghuninya sibuk beraktivitas di luar rumah. Pernikahan melahirkan ketenangan batin. Kesempurnaan eksistensi makhluk hanya tercapai dengan bergabungnya masing-masing pasangan dengan pasangannya. Allah telah menciptakan dalam diri setiap makhluk dorongan untuk menyatu dengan pasangannya apalagi masing-masing mau mempertahankan eksistensi jenisnya. Dari sini Allah menciptakan dalam diri mereka naluri seksual, yang dari hari ke hari memuncak dan mendesak pemenuhannya. Melalui kebersamaan dalam pernikahan, kekacauan pikiran dan gejolak jiwa itu mereda dan masing-masing memperoleh ketenangan. $^{42}$ Ini berarti, rumah tangga yang dibina dalam pernikahan idealnya mampu memberikan ketenangan dan kedamaian bagi penghuninya, dan bukan justru menjadi sumber konflik.

Di samping itu perkawinan juga bertujuan untuk mendapatkan keturunan yang sah dan saleh sebagaimana diisyaratkan dalam QS. al-Nahl (16): 72. jelasnya, bahwa melalui perkawinan akan dilahirkan anak cucu yang sah secara biologis dan hukum sehingga diharapkan akan memberikan kontribusi positif dalam pembangunan keluarga dan masyarakat yang beradab.

Menurut ajaran Islam, di samping alih generasi secara estafet, anak diharapkan dapat menyelamatkan orang tuanya (nenek moyangnya) sesudah meninggal dunia dengan memanjatkan doa kepada Allah. Bahkan anak menjadi investasi bagi kedua orang tua dalam menggapai keridaan Allah, sesuai petunjuk Nabi saw:

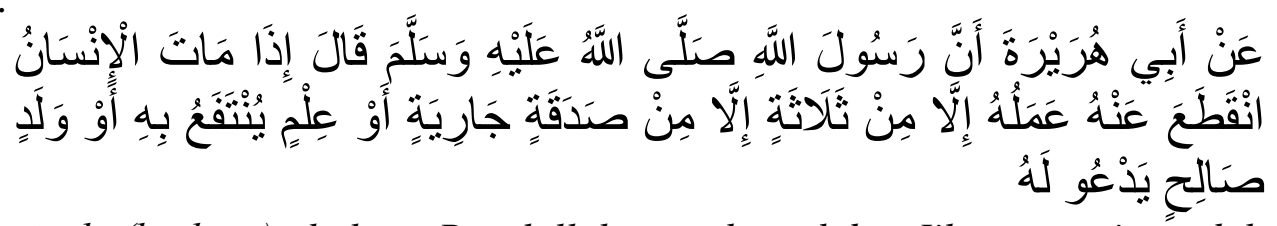

'Abu Hurairah (berkata), bahwa Rasulullah saw bersabda: Jika manusia sudah meninggal dunia, putuslah amalnya kecuali tiga perkara, yaitu sedekah jariyah, ilmu yang bermanfaat atau anak salehn yang mendoakan orang tuanya.' (HR Muslim $)^{43}$

Dengan demikian anak yang dilahirkan dalam sebuah perkawinan bukan saja dapat melanjutkan keturunan untuk meningkatkan kuantitas umat, namun juga dapat meningkatkan kualitas umat.

Namun demikian tujuan ideal perkawinan tersebut sulit diwujudkan, karena suami atau isteri yang menjalani operasi perubahan kelamin tidak bisa memberikan keturunan, bahkan tidak dapat pula memenuhi kebutuhan biologis pasangannya secara normal. Sebab pemenuhan kebutuhan biologis suami isteri secara normal merupakan dambaan setiap pasangan suami isteri. Perkawinan tanpa hubungan biologis suami isteri yang normal akan menimbulkan berbagai implikasi negatif bagi

\footnotetext{
${ }^{42}$ M. Quraish Shihab, Tafsir al-Misbah, Volume 11, hlm. 351.

${ }^{43}$ Abu al-Husain Muslim bin al-Hajjaj al-Qusyairi al-Naisaburi, Sahih Muslim, Juz I (Beirut: Dar al-Fikr, 1992), hlm. 242.
} 
kedua belah pihak baik secara psikologis maupun terhadap keutuhan rumah tangganya.

Dengan demikian operasi perubahan kelamin dalam implementasinya akan menimbulkan problem bagi waria tersebut serta orang lain yang berinteraksi sosial dengannya. Hal ini jelas tidak dibenarkan, karena Islam melarang seseorang untuk membahayakan orang lain, baik pada jiwanya, kehormatannya dan juga hartanya,

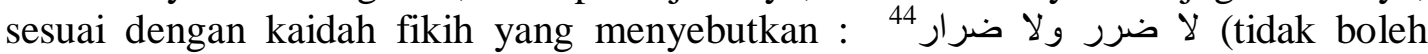
membahayakan orang lain dan membalas bahaya dengan bahaya).

Dari uraian di atas dapat dikemukakan bahwa kedudukan hukum waria dan banci (khunsa) mencakup beberapa aspek hukum, antara:

\section{- Dalam Kewarisan}

Pada prinsipnya operasi perubahan kelamin yang dilakukan seorang waria tidak dapat merubah posisi hukumnya dalam kewarisan. Karena pada hakekatnya dia berjenis kelamin laki-laki, walaupun waria itu telah berubah kelamin menjadi perempuan namun secara hukum ia adalah laki-laki. Hal ini sejalan dengan kaidah fikih yang menyebutkan : الأصل بقاء ما كان على ما كان (asal pada sesuatu adalah tetap pada keadaannya semula). ${ }^{45}$

Karena itu jika waria melakukan operasi perubahan kelamin, secara hukum kewarisan ia rugi karena hanya memperoleh satu bagian. Dengan demikian fatwa MUI tersebut pada hakekatnya jika diimplementasikan justru akan menguntungkan waria sendiri.

Berbeda dengan operasi penyempurnaan kelamin yang dilakukan oleh banci (khunsa) yang lebih memperjelas status hukumnya. Sehingga kalau setelah menjalani operasi penyempurnaan kelamin menjadi laki-laki, dia memperoleh dua bagian dari harta warisan. Sebaliknya jika setelah operasi penyempurnaan kelamin, menjadi perempuan, ia memperoleh satu bagian.

\section{- Dalam Perkawinan}

Operasi perubahan kelamin yang dilakukan oleh waria tidak merubah status hukumnya sebagai laki-laki. Jika ia kawin dengan lain jenis, perkawinannya merupakan perkawinan sejenis. Hal ini dilarang oleh Islam. Perkawinan sedemikian itu akan menimbulkan anak keturunan yang tidak sah dalam masyarakat.

Sedangkan status perkawinan bagi banci terkait dengan dasar hukum perkawinan itu sendiri, seperti wajib jika sudah mampu dan dikhawatirkan akan melakukan maksiat jika tidak kawin, sunnah jika sudah mampu tetapi masih bisa menahan diri, mubah bagi yang belum berminat kuat untuk kawin serta bisa menahan diri dari maksiat, haram bagi yang dapat menimbulkan ketidakharmonisan dalam keluarga atau bisa menyakiti pasangannya secara lahir dan batin karena jiwa dan perilakunya cenderung menyamai pasangannya, dan makruh yang tidak ada minat kawin. ${ }^{46}$

Jelasnya, jika ada banci yang menjalani operasi penyempurnaan kelamin yang kawin dengan pasangan yang tidak sejenis atau berjenis kelamin beda, status perkawinannya sama seperti manusia normal. Sedangkan waria yang menjalani

\footnotetext{
${ }^{44}$ Ali Ahmad al-Nadwi, al-Qawaid al-Fiqhiyah (Beirut :Dar al-qalam, 1420 H, hlm.288

${ }^{45}$ Lihat lebih lanjut dalam A. Djazuli, Kaidah-kaidah Fikih (Jakarta : Kencana, 2006), hlm.

${ }^{46}$ Abdul Azis Dahlan, et al. (ed.), Ensiklopedi Hukum Islam, Jilid 3, hlm. 935.
} 
operasi perubahan kelamin, walaupun dia kawin dengan lain jenis kelamin, namun tetap dilarang sebab hakekatnya waria tersebut menikah dengan sesama jenis kelamin, padahal perkawinan sesama jenis diharamkan dalam Islam.

\section{- Keturunan (nasab)}

Dalam hukum Islam, masalah keturunan terkait pula dengan sistem garis keturunan orang tua laki-laki (patrilineal dan matrilineal), banci atau khunsa baik yang ghayr musykil maupun yang musykil tanpa memperhatikan kecenderungan fungsi kelaminnya, secara otomatis akan mengikuti garis keturunan bapaknya. Jika banci menikah dan memiliki keturunan, anaknya juga akan mengikuti sistem garis keturunan bapaknya walaupun bapaknya bertingkah laku seperti perempuan. Demikian juga ibunya kendati bertingkah laku seperti laki-laki, kedudukannya tetap sebagai ibu dari anaknya. Jika kelak anaknya menikah, bapaknya itu tetap menjadi wali dari anaknya, dan bukan ibunya yang menjadi wali walaupun berperilaku seperti layaknya seorang bapak. ${ }^{47}$ (Abdul Azis Dahlan, et a, Jilid 3: 2001, 935).

Dengan demikian, seorang banci yang telah menjalani operasi penyempurnaan atau perbaikan kelamin, akan menjadi bapak atau ibu bagi anakanak yang lahir dalam perkawinannya. Bapak berhak menjadi wali dalam perkawinan anak perempuannya. Akan tetapi waria yang menjalani operasi perubahan kelamin, dalam realitas sulit mendapatkan keturunan sehingga walaupun secara teori dapat menjadi ibu atau bapak dari anak-anaknya namun secara realitas jarang terjadi.

\section{- Dalam ibadah}

Pada umumnya kewajiban melaksanakan ibadah bagi banci atau khunsa, baik ibadah wajib maupun sunat sangat tergantung pada fungsi kelamin yang dimilikinya. Keringanan dapat mereka peroleh kalau ibadah itu terkait dengan pemisahan persyaratan atau ketentuan antara laki-laki dan perempuan. Misalnya, dalam salat berjamaah, karena umumnya para banci (khunsa) memiliki sifat perempuan dibanding sifat laki-laki, mereka ditempatkan pada saf perempuan. Sehingga tidak wajib salat jumat. Jika ia haid, ia dilarang salat dan berpuasa serta mengqada puasanya. $^{48}$

Dengan demikian banci yang menjalani operasi penyempurnaan kelamin menjadi laki-laki dapat ditempatkan dalam saf laki-laki dalam salat berjamaah serta wajib mengikuti salat jumat. Sedangkan waria yang menjalani operasi perubahan kelamin menjadi perempuan pada satu sisi dia tetap tidak boleh menempati saf perempuan dalam salat berjamaah karena hakekatnya ia adalah laki-laki. Namun di sisi lain dia tidak bisa juga menempati saf laki-laki karena secara fisik setelah operasi adalah perempuan. Sehingga menimbulkan problem bagi dirinya. Secara hukum pula, ia tetap wajib salat jumat meskipun telah berubah jenis kelamin sebagai perempuan karena hakekatnya ia adalah laki-laki. Namun sulit juga dilakukan karena wujud fisiknya sebagai perempuan.

\footnotetext{
${ }^{47}$ Ibid.,

48 Ibid.,
} 


\section{KESIMPULAN}

1. Operasi kelamin yang bersifat tashih atau takmil (perbaikan atau penyempurnaan) dibolehkan dan penggantian jenis kelamin diharamkan. Hal ini disebabkan karena orang yang lahir dengan alat kelamin tidak normal bisa mengalami kelainan psikis dan sosial sehingga dapat tersisih dan mengasingkan diri dari kehidupan masyarakat normal serta kadang mencari jalannya sendiri, seperti melacurkan diri menjadi waria atau melakukan homoseks dan lesbianisme. Guna menghindari hal ini, operasi perbaikan atau penyempurnaan kelamin menjadi pilihan yang mesti dilakukan berdasarkan prinsip "Mashalih Mursalah" karena kaidah fiqih menyatakan "Adh-Dhararu Yuzal" (Bahaya harus dihilangkan) yang menurut Imam Asy-Syathibi menghindari dan menghilangkan bahaya termasuk suatu kemaslahatan yang dianjurkan syariat Islam.

2. Keberadaan penis (dzakar) atau vagina (faraj) yang berbeda dengan keadaan bagian dalamnya bisa mengganggu dan merugikan diri sesorang baik dari segi hukum agama karena hak dan kewajibannya sulit ditentukan apakah dikategorikan perempuan atau laki-laki, maupun dari segi kehidupan sosialnya. Untuk menghilangkan mudharat (bahaya) dan mafsadat (kerusakan) tersebut, syariat Islam membolehkan dan bahkan menganjurkan untuk membuang penis yang berlawanan dengan dalam alat kelaminnya.

\section{DAFTAR KEPUSTAKAAN}

Abdul Baqi, Muhammad Fu'ad. al-Lu'lu' wa al-Marjan. Diterjemahkan oleh Salim Bahreisy dengan judul Al-Lu'lu' wal Marjan: Himpunan Hadits Shahih Disepakati oleh Bukhari dan Muslim, Jilid 2, Cet. II; Surabaya: PT Bina Ilmu, 1982.

Abdul Jalil, dkk.. Fiqhi Rakyat Pertautan Fiqhi Dengan Kekuasaan, Cet. I; Yogyakarta: LKiS, 2002.

CD. Digital al-Hadis al-Syarif, Sunan al-Turmizi, kitab al-Tibb 'an Rasulillah, hadis nomor 1961.

Dahlan, AbduL Azis, et al. (ed.). Ensiklopedi Hukum Islam, Jilid 3, Cet. V; Jakarta: PT Ichtiar Baru van Hoeve, 2001.

------. Ensiklopedi Hukum Islam, Jilid 4, Cet. V; Jakarta: PT Ichtiar Baru van Hoeve, 2003.

------. Ensiklopedi Hukum Islam, Jilid 6, Cet V; Jakarta: PT Ichtiar Baru van Hoeve, 2001.

Departemen Agama R.I. Al-Qur'an dan Terjemahnya, Jakarta: CV Indah Press, 2002.

Departemen Agama R.I. Himpunan Fatwa Majelis Ulama Indonesia, Jakarta: Ditjen Bimmas Islam dan Penyelenggaraan Haji, 2003.

Hidayat, Komaruddin. "Agama dan Kegalauan Masyarakat Modern." dalam Nurcholish Madjid (ed.). Kehampaan Spiritual Masyarakat Modern Respon dan Transformasi Nilai-Nilai Islam Menuju Masyarakat Madani, Cet. I; Jakarta: Madiacita, 2000.

Ibn Hanbal, Ahmad. Musnad Ahmad bin Hanbal, Juz III, Bayrut: Dar al-Fikr, [t.th.]. 
Kartono, Kartini. Psikologi Abnormal dan Abdnormalitas Sexual, Bandung: CV Mandar Maju, 1989.

Al-Munawar, Said Agil. "Perkembangan Ilmu Pengetahuan dan teknologi serta rekayasa Teknologi Genetika dalam Perspektif Islam.” Dalam Muhammad Azhar Hamim Ilyas (ed.). Pengembangan Pemikiran Keislaman Muhammadiyah: Purifikasi dan Dinamisasi, Cet. I; Yogyakarta: M ajelis Tarjih dan Pengembangan Pemikiran Islam PP Muhammadiyah dan LIPPI, 2000.

Madjid, Nurcholish. Masyarakat Religius, Cet. I; Jakarta: Paramadina, 1997.

Al-Naisaburi, Abu al-Husain Muslim bin al-Hajjaj al-Qusyairi. Sahih Muslim, Juz I, Bayrut: Dar al-Fikr, 1992.

al-Qardawi, Yusuf. Hady al-Islam Fatawi Mu'asirah. Diterjemahkan oleh Abdul Hayyie al-Kattani, dkk dengann judul Fatwa-Fatwa Kontemporer, Jilid 3, Cet. I; Jakarta: Gema Insani Press, 1995.

Puspitosari, Hesti dan Sugeng Pujileksono. Waria dan Tekanan Sosial, Cet. I; Malang: UMM Press , 2005.

Shihab, M. Quraish. Tafsir al-Misbah: Pesan, Kesan dan Keserasian Al-Qur'an, Volume 2, Cet. III; Jakarta: Lentera Hati, 2005.

------. Tafsir al-Misbah Pesan, Kesan dan Keserasian Al-Qur'an, Volume 11, Cet. III; Jakarta: Lentera Hati, 2005.

Srintil (ed.). Menggugat Maskulinitas dan Feminitas, Jakarta: Kajian Perempuna Desantara, 2003.

Al-Turmizi, al-Jami' al-Sahih Wahuwa Sunan al-Turmizi, Juz III, Bayrut: Dar alFikr, [t.th.].

Utomo, Setiawan Budi. Fiqih Aktual Jawaban Tuntas Masalah Kontemporer, Cet. I; Jakarta: Gema Insani Press, 2003.

Zuhdi, Masjfuk. Masail Fiqhiyah, Cet. X; Jakarta: PT Toko Gunung Agung, 1997. 